\title{
War-Making Under the Constitution: The Original Understanding
}

\author{
Charles A. Lofgrent
}

The first major public debate over the division of war-making power between Congress and the President occurred in mid-1793 following President Washington's proclamation of American neutrality ${ }^{1}$ in the war which had broken out between England and France at the beginning of that year. Defending Washington's action in a series of newspaper articles under the disarming pseudonym of "Pacificus," Alexander Hamilton, a participant in the Constitutional Convention six years earlier, argued that since war-making was by nature an executive function, Congress could exercise only those aspects of it which the Constitution specifically grants the legislature. These grants, being exceptions to the general rule, must be narrowly construed.a James Madison, a principal framer of the Constitution and co-author with Hamilton and John Jay of The Federalist Papers, found the Constitution equally clear, but to the opposite effect. Writing as "Helvidius," Madison asserted that war-making was a legislative function and that any exceptions in favor of the executive must be strictly interpreted. ${ }^{3}$

The debate thus opened has continued sporadically to the present day. Most recently, limited wars in Korea and Indochina have occisioned renewed interest in the question of which branch of the federal government is constitutionally empowered to commence war. ${ }^{4}$ In the

+ Associate Professor of History, Claremont Men's College. B.A. 1961; M.A. 1962; Ph.D. 1966, Stanford University. The author is indebted to Protessors Keith Berwick, Lconatd Levy, and John Niven for comments on an earlier draft; to the staffs of the Henty 1:. Huntington and Los Angeles County Law Libraries for their assistance and kindnesses; and to the Faculty Research Committee of Claremont Men's Collegc and the Relin Foundation for financial support.

1. Proclamation of April 22, 1793, I Americin State Papers: Fokeign Relations 140 (WW. Lawrie \& M. Clark eds. 1833).

2. See 4 The Works of Alexander Hamilton 437-44 (H. Lodge ed. 190.1). Specific exceptions to the President's war-making power, as listed by Hamilton, were "the right of the Legislature "to declare war and grant letters of marque and reprisal":" Id. at 439. See U.S. Const. art. I, $\S 8$.

3. See 6 The Writincs of James Madison 138.88 passim (G. Hunt cd. 1906). Under Madison's interpretation, the key exception to the war-making power of Congress was the provision that the President was "Commander in Chief of the Army and Navy of the United States, and of the militia when called into the actual service of the United States." Id. at 148. See U.S. CoNST. art. II, $\$ 2$.

4. The literature on this topic is enormous. Useful introductions may be found in Hearings on War Powers Legislation Before the Subcomm. on National Sectrity Policy and Scientific Developments of the House Comm. on Foreign Affairs, 92d Cong., 1st Sess. 
course of this debate, however, constitutional scholars have generally failed to examine thoroughly the problem of how Americans in 1787. 88 understood the war-making clauses of the Constitution.5 Such scholarly reticence ${ }^{6}$ doubtless has some claim to prudence since Madison and Hamilton, who presumably knew something about the original intent, came to contradictory conclusions within a few years of the Constitutional Convention. But the fact that two of the framers were in disagreement is thin justification for according this significant issue inadequate treatment. Hence, by examining the debates and proceedings which accompanied the framing and ratification of the Constitution, and particularly by considering ideas prevalent among Americans of that day as they interpreted the clauses in question, I shall attempt in this article to throw light on two important questions: (1) What was the original understanding respecting the allocation between the President and Congress of the general power to commence war? And (2) was that power understood to include the commencement of undeclared war?

(1971); Hearings on Congress, the President, and the W'ar Pouters Before the Subcomm. on National Security Policy and Scientific Developments of the House Comm. on Forcign Affairs, 9lst Cong., 2d Sess. (1970); M. PuSEY, THE WAY W'E Go To War (1969): Notc. Congress, the President, and the Power to Commit Forces to Combat, 81 Hanv. L. REv. 1771 (1968); E. Corwin, The President: Office ANd Powers 1787-1957: Histors and ANalysis of Practice and OpINion (4th rev. ed. 1957): Holse Comat. on FonejGN Affains, Background INformation on the Use of United States ArMegd Forges in Fonelgn CoustRIEs, H.R. REP. No. 127, 82d Cong., Ist Sess. (1951). For earlier studies, ste J. Rocens, World Policing and the Constitution: An INouiro into the poners of tile presidest and Congress, Nine wars and A Hundred Mfilttaky Orerations 1789.1945 (1945); C. Berdahl, War Powers of the Executive in the United States (1921).

5. The clauses of primary significance are art. $I, \$ 8$, empowering Congress "[t]o declare War [and] grant Letters of Marque and Reprisal ...." and art. If, $\$ 2$, making the President "Commander in Chief of the Army and Navy of the United States, and of the Militia of the several States, when called into the actual Service of the United States ...." Of lesser importance is the clause of art. I, \$ 10, providing that "[I] State shall ... engage in War, unless actually invaded, or in such imminent Danger as will not admit of delay." The clauses of art. I, § 8, dealing with the raising, support, goternment, and regulation of land and naval forces-that is, the war-supporting clauses-are outside the scope of the present study. For debate surrounding them, see Donahoc \& Smelser, The Congressional Power to Raise Armies: The Constitutional and Ratifying Conventions, 1787-1788, 33 Rev. OF POL. 202 (1971).

6. Recent commentators have discussed the original understanding, but, regardless of their positions on present-day issues, they have generally limited such discussions 10 an examination of the one debate in the Federal Convention on changing the wording of the clause giving Congress the power "to make war" so that it conferred power "10 declare war." For this debate, see 2 THE Records of tIIE Federal Convestion 318.19 (MI. Farrand ed., rev. ed. 1937) [hereinafter cited as FARRANd, Records]. Sec, e.g., $1970 \mathrm{Hear}$ ings on Congress, The President, and the War Pouers, supla note 4, at 207, 211 (statcments of J. Stevenson, Legal Advisor, Dep't of Statc, and I'. Rchnquist, . Iss't Att'y Gen.); Bickel et al., Indochina: The Constitutional Crisis, in 116 CoNG. REc. 7117, 7122.23 (daily) ed. May 13, 1970); PuSEY, supra note 4, at $44-47$ (treating some other points, but only vaguely); Note, Congress, the President, and the Power to Commil Forces to Combat, supra note 4, at 1773 \& nn.14, 16; Wormuth, The Vielnam W'ar: The President versus 


\section{Problems of Allocating Power: From the Articles of Confederation to the Constitution}

Under the Articles of Confederation, Congress exercised both legislative and executive powers. Consequently, the Articles, in dealing with the war-making power, needed only to provide that the "United States in Congress assembled, shall have the sole and exclusive right and power of determining on peace and war." (An exception provided that individual states might engage in war if they were actually in. vaded or were threatened with imminent Indian attack.) ${ }^{\top}$ Like the Constitution, however, the Articles today appear somewhat ambiguous on their face as to whether a war conducted by the United States necessarily had to be a "declared" war. They conferred the "right and power of determining on . . . war," but also referred to certain acts the states might perform only after a congressional "declaration of war." 8 Thus, while contemplating that at least some wars would be "declared" in form, the document did not explicitly resolve the question of whether the nation might engage in other sorts of war. ${ }^{0}$

Whatever the case with the Confederation, in 1787 the Philadelphia Convention drafted a Constitution which provided for a federal gov. ernment with distinct branches, thereby necessitating some attention to the allocation of the war-making power of the government. Yet, while the new Constitution increased the already severe limitations

the Constitution, in 2 THE VIETNAM WAR AND INTERNATIONAL LAW 710, 713-17 (R. Falk ed. 1969); R. Hull \& J. Novogrod, Law and Vietnam 170 (1968). But see Revelcy, Presi. dential War-Making: Constitutional Prerogative or Usurpation?, 55 VA. L. REv. 1248, 1281-85 and accompanying notes (1969) (citing other evidence from the convention itself); R. Russell, The United States Congress and the Power to Use Military Force Abroad, April 15, 1967, at 1-65 (unpublished Ph.D. dissertation in the Fletcher School of Law and Diplomacy Library, Tufts University). While Russell neglects several points discussed in the present article, see especially pp. 680.83 \& pp. 688.99 infra, and gives less attention to certain other items, see especially pp. 683.88 infra, his conclusions are generally con. sistent with mine. Deserving special mention is Hearings on War Pou'ers Leyislation Before the Senate Comm. on Foreign Relations, 92d Cong., 1st Scss. at 7.121 passim (1972) (statements and testimony of Professors H.S. Commager, R. Morris, and A. Kelly, Mar. 8.9, 1971), which I was able to examine only after the present article was written. This pro. vides an excellent, albeit relatively brief, discussion of the original undestanding of $\mathbf{1 7 8 7} .88$ in the course of a broader review of the history of war-making in its constitu. tional dimensions.

7. ARTs. OF CoNFED. arts. VI, IX. These provisions relating to war-making in the final Articles of Confederation were virtually unchanged from the first draft of the doctument in July 1776. See 5 Journals of the Continental Congress 1774-1789, at 549.50 (1906). 8. Arts. Of Confed. arts. VI, IX (italics added).

9. Since the Articles did authorize the granting of letters of marque and reprisal, the) tacitly suggest that other sorts of hostilities were contemplated. Much depends, however, on the types of situation to which letters of marque and reprisal were thought applicable, and on whether such situations were to be classified as war. The same ambiguity ariscs with respect to the Constitution and is discussed at pp. 692.96 infra. 
which the Articles of Confederation had placed on state war-making, ${ }^{10}$ similar explicitness did not mark the division of war-making power between Congress and the President. Nor have the records of the debates in the Federal Convention proved an adequate guide in resolving the ambiguities inherent in the "plain words" of the Constitution, principally because the question of the manner in which the nation should be committed to war was not one of the chief concerns of the delegates in Philadelphia. Criticism of the Confederation government for its inability to support federal objectives, both domestic and foreign, had not included the complaint that the Confederation was deficient in its ability to commit the nation to war. ${ }^{11}$

The main report of the one debate which explicitly considered allocation of the war-making power occupies little more than one page out of the 1,273 which contain the printed records of the Convention. ${ }^{12}$ This debate occurred on August 17, 1787, while the Convention was considering the clause of the draft constitution reported by the Committee on Detail on August 6 which gave Congress the power "to make war."13 Charles Pinckney of South Carolina opened the debate by arguing that the legislature as a whole was too cumbersome a body to exercise this power. He contended that it should be vested in the Senate, which was smaller and would be more knowledgeable in foreign affairs, and which by virtue of its treaty power ${ }^{14}$ had the authority to make peace. Pierce Butler, from Pinckney's own state, carried the latter's argument a step further and called for vesting the power in the President, but his proposal received no recorded support. Madison and Elbridge Gerry of Massachusetts then "moved to insert 'declare'; striking out 'make' war; leaving the Executive the Power to repel sudden attacks." 15 .This wording, from Madison's notes, suggests that the change from "make" to "declare" was intended in some fashion to broaden the executive's power in the war-making area.

The available record of the remainder of the debate indicates, how-

10. Under the Articles, states could grant letters of marque and reprisal after a congressional declaration of war, subject to congressional regulation, while under the Constitution they are absolutely forbidden to make such grants. Compare ArTs. OF CoNFED. art. VI, with U.S. CoNsT. art. I, § 10.

11. See Farrand, The Federal Convention and the Defects of the Confederation, 2 AM. Pol. Scr. Rev. 532, 535-37 (1908).

12. See 2 Farrand, Records, supta note 6, at 318-19.

13. Id. at 181-82.

14. At this point in the Convention's proceedings, the Senate still had cxclusive authority to make treaties, the President not yet having been given power to make treaties with the advice and consent of the Senate. See id. at 183, 392-94, 498, 538.

15. Id. at 318 (emphasis added). 
ever, that the delegates may not have understood the change in such an unambiguous way, or indeed in any one way at all. For example, Roger Sherman of Connecticut protested that the clause as originally reported, that is, without the Madison-Gerry amendment, "stood very well. The Executive shd. be able to repel and not to commence war. 'Make' better than 'declare' the latter narrowing the power too much." It thus appears that Sherman believed that the original wording already left the executive free to repel sudden attacks and hence that in this respect the proposed change was nugatory. But he apparently thought that by narrowing the power of Congress, the alteration would unduly broaden the executive's power in some other ways. Oliver Ellsworth, also of Connecticut, at first concurred with Sherman in opposing the change. George Mason of Virginia, who "was against giving the power of war to the Executive, because [he was] not safely to be trusted with it; or to the Senate, because [it was] not so constructed to be entitled to it ... and was for clogging rather than facilitating war," and who on that basis might well have agreed with Sherman and Ellsworth, instead supported the change. Madison's notes indicate that at this point a vote on the proposed change was taken, resulting in a tally of seven states to two in favor of the amendment. Then, in the face of an argument advanced by Rufus King of Massachusetts 'that 'make' war might be understood to 'conduct' it which was an Executive function," Ellsworth accepted the need for the alteration in wording and Connecticut switched its vote, making the poll eight to one in favor of the Madison-Gerry amendment.16

In editing the records of the Convention, Max Farrand concluded that the official journal of the Convention, as regards the votes taken, was at times unreliable, inconclusive, or both, ${ }^{17}$ and for this reason Madison's figures are used here. If accurate, these figures indicate that King's argument had but a marginal effect on the fate of the Madison-Gerry amendment, since it would have passed without Connecticut's vote. But this is a case where the journal figures do not accord with Madison's. The journal indicates that the Madison-Gerry amendment initially lost by a vote of four states to five and that it was

16. Id. at 318-19. See also Note, Congress, the President, and the Power to Commit Forces to Combat, supra note 4 , at 1773 n.16. Only nine states cast votes becatise Massit. chusetts abstained on the isste, New Jersey and New York were not represented at this point, and Rhode Island never attended the Convention.

17. I Farrand, Records, supra note 6, at xiii-xiv. Madison himself later "corrected" some of his information to bring it into conformity with the journal, but such cmendit. tions were not made in his notes of the debate under discussion. 
only on the second vote that the amendment carried-by an eight to one margin. ${ }^{18}$ If the journal is accurate in its voting figures and if King's argument was the key statement made between the two votes, then it had a far greater effect on the outcome than Madison's account would suggest.

The "ifs" must remain, for the record is unclear. The only certainty which emerges from the debate is that the wording was changed. What the various delegates thought the change accomplished can only be set forth in terms of possible interpretations: (1) the change broadened executive power by giving the executive the authority "to repel sudden attacks"; (2) the original wording already having given the executive that power, the alteration broadened his power in some more general fashion; (3) the modification lessened the chance for involvement in war; or (4) the new wording removed any suggestion that Congress would control the conduct of a war after it was begun. Of these possibilities, the first two suggest an intention to broaden the executive's power in some way. The third, and particularly the statement of Mason from which it is derived, does not bear clearly one way or the other on the question of executive-versus-legislative power. The fourth possibility suggests that the change referred to something other than the process of initially committing the nation to war. As if to reinforce the conclusion that the change meant different things to different delegates, Butler of South Carolina, after the new wording had been approved, "moved to give the Legislature [the] power of peace as they were to have that of war."10 In his mind, it seems, the Madison-Gerry amendment had done little. The legislature still had the power "of war."

\section{Indications of an Original Understanding}

If the discussion and votes on August 17 were the only source of evidence revealing the original understanding of war-making under the Constitution, those eager for a definite conclusion would have due cause for despair. But the private intentions of the Convention's delegates in changing "make" to "declare," whatever they were, did

18. 2 id. at 313-14. Russell appears more convinced than I am that the journal's record of these votes is accurate, and he suggests that Madison may have mislabeled one of the vote counts. His position on the largely inconclusive meaning of the debate is, however. close to mine. See Russell, supra note 6, at $39-43$.

19. 2 FARRAND, ReCoRds, supra note 6 , at 319. 
not control the way Americans of that day generally understood the Constitution's war-making clauses. Fortunately, we can gain additional and more conclusive evidence from (a) other deliberations of the Federal Convention and the Constitution itself; (b) the state debates over the ratification of the Constitution; (c) some seventeenth and eighteenth century trends in the theory and practice of war and reprisal; and (d) a consideration of English influences.

\section{A. The Convention and Its Product}

In 1787 and 1788, Americans ratified the Constitution, not a set of proceedings in the Federal Convention. ${ }^{20}$ In fact, the Convention's records remained largely secret for thirty years."1 Still, the deliberations in Philadelphia are worth examining for clues as to how Americans of that day generally understood war-making in its constitutional dimensions. The Convention's members were, after all, members of and leaders in a broader community, so it is likely that their fundamental assumptions were shared by other Americans. In addition, the Constitution itself provides clues to how the delegates' contemporaries understood war-making under it.

The plan of government submitted by Edmund Randolph on behalf of Virginia became the focus of the Convention's first deliberations. It contained no specific reference, however, to the power of either the executive or the legislative branch to commit the nation to war, ${ }^{22}$ but instead neatly side-stepped the question. Randolph recommended that the "National Legislature ... ought to be impowered to enjoy [among other things] the Legislative Rights vested in Congress by the Confederation" and that the "National Executive ... ought to enjoy the Executive rights vested in Congress by the Confederation." ${ }^{23}$ The only recorded remarks bearing on how such criteria for division might affect the allocation of war-making power came on June 1, 1787. Charles Pinckney cautioned that the powers of war and peace might properly be classed as executive powers. James Wilson of Pennsylvania, although admitting his preference for " $\mathrm{a}$ single magistrate, as giving most energy dispatch and responsibility to the office [of National Executive]," took exception: "[h]e did not

20. See, e.g., $1 \mathrm{~J}$. Story, Commentaries on the Constitution of the United Statres 388-90 (1833).

21. I FarRand, Records, supra note 6 , at xi·xv.

22. See id. at 18-23.

23. Id. at 21 . 
consider the Prerogatives of the British Monarch [which included the power of making war] as a proper guide in defining the Executive Powers. Some of these prerogatives were of a Legislative nature. Among others that of war \& peace \&c." Madison agreed with Wilson, ${ }^{24}$ but the resolutions which the Convention eventually passed and sent to the Committee on Detail on July 26 were no more explicit regarding the division of war-making power than Randolph's original plan had been. In a sense they were even less explicit because they did not contain the general proposition that the executive should enjoy the executive powers vested in the Confederation Congress. ${ }^{25}$

Despite the paucity of prior debate and the ambiguity of the resolutions sent to it, the Committee on Detail had little trouble in allocating the war-making power. Randolph and Wilson each prepared draft constitutions which assigned the power "to make war" to the legislature. The draft reported by the committee to the Convention on August 6 followed the same scheme. Clearly, as the committee sensed the will of the Convention on these points-points which, it must be remembered, had scarcely been debated-war-making fell almost automatically to Congress. At the same time, the committee made the executive, now denominated the President, the Commander in Chief of the armed forces. In view of the concurrent grant to Congress of the broad power "to make war," the Presidency did not carry with it any authority to initiate war, except perhaps the restricted power of repelling sudden attacks which Sherman was soon to attribute to it. After the committee reported, the Convention spent a month debating and sometimes modifying its recommendations, changing, inter alia, Congress' power "to make war" to a power "to declare war." The Commander-in-Chief clause, however, was passed unchanged and without recorded debate on August 27, 1787. This expeditious, unremarked assent again suggests a narrow, non-controversial conception of the clause. ${ }^{26}$

Charles Pinckney's recommendation that Congress be given the power to grant letters of marque and reprisal was approved on September 5. Perhaps, as Joseph Story later contended, the Convention

24. Id. at $64-65,70$.

25. See 2 id. at 129-34.

26. These developments can be traced in id. at 143, 145, 168, 172, 182, 185, 426.25: p. 676 supra. On the narrow view the Comvention took of the President's role as Commander in Chief, see especially May, "The President Shall Be Commander in Chief" (1787-1789), in The Ultimate Decision: The President is Cominasder in Cinef 3.19 (E. May ed. 1960). 
desired to remove any remaining doubt about the authority of Congress to authorize some form of undeclared hostilities. ${ }^{27}$ At the least, it thus became possible for Americans in 1787-88 to draw such a conclusion, with their precise interpretation of the scope of the power depending on how they understood the purpose of letters of marque and reprisal. ${ }^{28}$ The Convention's final product contained all three provisions: Congress received the power to declare war and to grant letters of marque and reprisal, and the President became Commander in Chief. ${ }^{20}$

The Convention also left several less direct clues to how the delegates and their contemporaries may have understood the Constitution's war-making provisions. One is found in the plan of government that Alexander Hamilton presented to the Convention on June 18. This discloses that Hamilton, despite his preference for a greatly strengthened executive, was inclined to limit severely the executive's role in initiating war. He would have given the Senate, not the President, "the sole power of declaring war." The President was instead "to have the direction of war when authorized or begun." 30 His scheme also supports the conclusion that the delegates and their contempo. raries in America did not understand the term "declare" in a narrow, technical sense. On Hamilton's theory the President could direct war only after it had been commenced. His sole reference to the commencement of war, however, was the grant empowering the Senate to declare it-yet not even in the eighteenth century were all wars technically "declared." 31

27. See 2 FARRAND, RECORds, supra note 6, at 326, 508.09; 3 STORY, supra note 20, at 63.64.

28. Despite Justice Story's comment, recent students of the war-making isstte have generally neglected the significance of the power to grant letters of marque and reprisal, which is discussed at pp. 692-96 infra. For an example of the complete omission of this power from a list of "specific powers relevant to [the] discussion" of the original understanding, see Rogers, Congress, the President, and the War Powers, 59 CALIF. L. Rev. 1194,1195 (1971). Secretary of State Rogers' article appeared carlicr as a preparcd state. ment in 1971 Hearings on War Powers Legislation, supra note 4 , at 122.

29. U.S. CoNSr. art. I, \& 8, art. II, \& 2.

30. 1 FARRAND, ReCords, supra note 6, at 292 (emphasis added). Notes on the plan Hamilton presented to the convention on June 18 are found in id. at 282.93. The version he presented in draft form to Madison late in the convention is in 3 id. at 617.30. On Hamilton generally during the Convention, see B. Mitchell, Alexander Hamitron: Youtit to Maturity 1755.1788 , at $389-413$ (1957); J. Miller, Alexander Hamilton and thle Growth of The NEw Nation 151.83 (1964).

31. During the debate of August 17, on the war-making clause, Elbridge Gorry (or perhaps Madison in recording Gerry's remarks) had used "declare" in a similarly loose sense. Pierce Butler proposed "vesting the power [i.e., the power to make war, since thic amendment to change the wording had not yet been proposed] in the 'resident." Gerry, commenting after Madison's and his amendment to change the wording had been offered but before it had been voted on, and with evident reference to Butler's remark, soon objected that he "never expected to hear in a republic a motion to cmpower the Exectl- 
Another clue is provided by the placement within the Constitution of the restrictions on the power of the states to wage war independently of the central government. In Philadelphia, limitations even stricter than those which had been included in the Articles ${ }^{32}$ emerged during the deliberations of the Committee on Detail and were included as separate coordinate articles in the draft reported by that committee to the Convention. The Committee on Style, however, placed the prohibitions in the legislative article, where they appear in the final Constitution..$^{33}$ If the Committee on Style decided on this arrangement by reasoning that any authority possessed by the states to make war would derogate from the power of the new Congress, the committee assumed something that the Convention had never explicitly resolved-namely, that commencing war is properly a legislative function. Like the earlier action by the Committee on Detail in assigning the power "to make war" to Congress, the Committee on Style's action suggests that there was no need for clarification by the Convention, since the notion was generally accepted.

Two points may detract from the soundness of this conclusion. First, the limitations on states placed in Article I included restrictions on the foreign relations power of the states. ${ }^{37}$ This would imply, using a similar argument based on placement, that the delegates also viewed foreign relations as properly within the legislative sphere, despite the apparent fact that the President was given substantial power in the foreign relations area. Offsetting the contention that on this account the argument based on placement is unsound is the fact that the Convention did provide the Senate with a check on the President's treaty-making powers, a check that George Washington at first took especially seriously. ${ }^{35}$ In addition, it gave Congress far

tive alone to declare war." 2 FARRAND, RECORDS, supra note 6, at 318 (cmphasis added). Whether the precise wording in Madison's notes is an accurate rendition of Gerry's usage or whether it reflects Madison's imprint is immaterial. Either alternative supports the conclusion that "declare" did not have a very strict meaning in current Ameriean usage. This conclusion is elaborated at p. 685, pp. 693-96 infra.

32. See note 10 supra.

33. See 2 Farrand, Records, supra note 6, at 169, 187, 577, 597; U.S. CoNst. art. I, § 10: "No State shall ... grant letters of Marque and Reprisal . . . [nor,] without the Consent of Congress, ... engage in War, unless actually invaded, or in such imminent Danger as will not admit of delay."

34. "No State shall enter into any Treaty, Alliance, or Confederation . . . [nor.] without the Consent of Congress, ... enter into any Agrecment or Compact with another State, or with a foreign Power ...."U.S. CoNsr. art. I, \$ 10. Neither here nor in the restrictions on state war-making did the final document contain any substantive changes from the report of the Committee on Style.

35. See R. Haiden, The Sevate and Treaties 1789-1817, at 1-106 (1920). Hajden concludes that "Washington made treaties 'by and with the advice and consent' of the Senate in a sense and to an extent that no later President erer has." Id. at 103. 
more power than the President in what contemporaries hoped and thought would be the dominant and proper form of America's relations with the world-commercial relations. ${ }^{30}$ Similarly detracting from the force of the argument based on placement is the fact that we simply do not know much about the considerations which guided the Committee on Style. ${ }^{37}$ It is quite possible that in placing the restrictions on state war-making, the committee and its chief drafts. man, Gouveneur Morris of Pennsylvania, were not concerned with the implications just discussed. Yet the suspicion remains that something more than style prompted the committee's change, since the limitations could easily have been continued as one or more separate articles or else placed in Article IV, which contains other provisions relating to the states. In any event, placement of the state war-making restrictions may have contributed to a general impression that Con: gress was intended to be dominant in the field.

A final indirect clue to how Americans in the late 1780's understood war-making under the Constitution comes from the provision that states may not engage in war "unless actually invaded, or in such imminent Danger as will not admit of delay." 38 Although the Convention had given some attention to the issue of surprise attack during its one debate over the main war-making grant to Congress, ${ }^{30}$ this is the only explicit reference to the matter in either the completed Constitution or the earlier drafts. While the provision may appear inconsequential to a late twentieth century observer, it undoubtedly had far more meaning in the 1780's when communications and trans. portation would not have allowed an immediate federal response to a truly surprise attack. In such a situation, the real problem would have been whether states might act prior to a national decision. The provision allowing state action may have seemed more consequential, too, both because state-versus-federal authority was a major issue in the general constitutional controversy of the day, and because the Constitution otherwise narrowed the sphere of permissible state activity in the war-making area. Yet the completed Constitution contained no indi-

36. See, e.g., P. Varg, Foreign Policies of the Founding Fathers 1.69 (Penguin cd. 1970); G. Stourzh, Benjamin Franklin and American Foreign policy 238.46 (2d cl. 1969); F. Gilbert, The Becinnincs of american fopeign Policy: To The fanewell ADDREss passim (1965).

37. See Letter from James Madison to Jared Sparks, April 8, 1831, in 3 FAkณ ND, RECoRds, supra note 6, at 498, 499; C. Rossiter, 1787: THE GrANd Convention 224.80 (1966); M. Farrand, The Framing of the Constitution of the United States 181.82 (1913).

38. U.S. Covsr. art. I, § 10.

39. See pp. 675-77 supra. 
cation that the states were to have exclusive responsibility to meet surprise attack. 0 In sum, the question of how an observer in the late 1780 's would have interpreted the provision cannot be definitively answered, but its presence in the Constitution at least further suggests that Americans of that day need not have envisaged that the President as Commander in Chief would have an especially broad role in repelling sudden attack.

\section{B. The State Ratification Debates}

The state ratification debates, like the Philadelphia Convention, were little concerned with how the new government would initiate war. As an example, five of the eleven states which ratified the Constitution before the new government commenced operation offered amendments to it, but of the seventy-seven amendments thus proposed, only one-from New York-dealt with the power of Congress to declare war. Moreover, that proposal, to require a two-thirds vote in each house of Congress for a declaration of war, was designed to protect state or regional interests rather than to alter the balance of war-making power between Congress and the President. By contrast, twenty-eight of the proposed amendments concerned elections and procedures under the new government, fourteen dealt with individual rights and privileges, nine with taxation and finance, six with the raising and maintenance of armies and control of the militia (i.e., the war-sup. porting function) and five each with commerce and the jurisdiction of courts. ${ }^{41}$

Contemporary newspaper, pamphlet, and state convention debates display a similar lack of attention to the allocation of the war-making power. Although, for example, the first North Carolina convention eventually found the Constitution objectionable enough not to ratify

40. See also p. 687 infra.

41. See Ames, The Proposed Amendments to the Constitution of the United States During the First Century of Its History, in 2 ANNUAL Rerort OF THE AMEnican Histonicit. Association FOR THE YEAR 1896, at 307.09 (1897). For the texts of the amendments, sce 1 Debates in the Several State Conventions on tie Adomtion of the Feneral Constitu. TION 322-31 (J. Elliot ed. 1888); 3 id. at 659-61 [hercinafter cited as Eluor, Denates]. The five states offering amendments in order of ratification, were Masachusctus, South Carolina, New Hampshire, Virginia, and New York. The amendments nearly proposed by Maryland, those declared by the first North Carolina convention to be necesary be. fore that state ratified, and those proposed by Rhode Island in its tardy ratification also support the conclusions in the text. See Ames, supra, at 309.10; 1 Elctor, Demtres 396.37; $2 \mathrm{id}$. at $550-53 ; 4 \mathrm{id}$. at 244-47. In several instances my classification of an amendment differs from that of Ames. In any event, only the New York amendment noted in the text and another New York amendment to prohibit the President as Commander in Chice from commanding the Armed Forces in person (both of which are in 1 id. at 330) bore on the external war-making powers of the proposed government. 
it, the clause giving Congress the power "to declare War [and] grant Letters of Marque and Reprisal" was "read without any observation." 42 James Winthrop in Massachusetts and Richard Harry Lee in Virginia both objected to the increased centralization which characterized the proposed government, but both agreed that the power of war could, in Lee's words, "be lodged no where else, with any propriety, but in this [the central] government." 43 The explicit restrictions on state war-making in the Constitution received almost no attention, adverse or otherwise, in the state debates. ${ }^{44}$ Though the authors of The Federalist Papers were not above beating a straw man in arguing their case, ${ }^{45}$ in Number 41 Madison commented: "Is the power of declaring war necessary? No man will answer this question in the negative. It would be superfluous, therefore, to enter into a proof of the affirmative." 46 The existing Confederation government already held the power to make war. Its presence in the Constitution could hardly be a matter of controversy. In addition, the war-making power did not have the direct connection with such broader issues as state-versus-federal taxation and civilian-versus-military rule that the war-supporting powers had-the latter connection producing considerable debate. ${ }^{47}$

Yet, again like the Philadelphia Convention, the state debates offer revealing, albeit indirect and sometimes inferential, evidence about how contemporaries understood the Constitution's war-making clauses. Significantly, several comments strongly hint that Americans in 1787-88 thought the power to declare war assigned to the new Con-

42. 4 id. at 94 .

43. EsSays on the Constitution OF THE UNITED States 1787-1788, at 98 (P. Ford ed, 1892) [hereinafter cited as Ford, Essays]; PAMPhLETS on the Constirution of thiE United StATES 1787-1788, at 300-01 (P. Ford ed. 1888) [hereinafter cited as Fokd, PAsmiLers].

44. "Almost," because Madison made cursory mention of them. See Tite Federalist' No. 44 (J. Cooke ed. 1961) (except as noted, all citations herein to The Federalist arc to the definitive Cooke edition).

45. Publius argued that opponents of the Constitution were proposing a series of regional confederations in place of a federal union, but the latest study of the ratification controversy in New York finds practically no talk of this sort among the state's antifed. eralists. See The Federalist Nos. 3, 5 (J. Jay), No. 13 (A. Hamilton); L. DePAuw, 'TuL Eleventu Pillar: New York State and the Federal. Constitution 173 (1966).

46. The Federalist No. 41, at 269-70. I have sought to avoid over-reliance on $T / 1 E$ Federalist as a guide to the original understanding. As Professor McLaughlin remarked years ago, "[T] $[\mathrm{T}$ hese essays were probably of service in winning support of the Constitution; but the extent of that service we naturally cannot measure. For much immcdiate practical effect they were perhaps too learned, too free from passion. . . . The Federalist probably had more effect after the new government went into operation than in the days of uncertainty when the fate of the union seemed to hang in the balance...." Mclauchlin, A Constitutional History of the United States 208.09 (1935).

47. See Donahoe \& Smelser, supra note 5 , and the citations containcd thercin; $A$. Ekirch, The Civilian and the Military 27-31 (1956). 
gress was practically identical with the old Congress' power of determining on war. After stating in The Federalist Number 41 that it would be superfluous to examine whether the power of declaring war was necessary, Madison remarked: "The existing confederation establishes this power in the most ample form." 48 In the New York convention John Jay implicitly equated the power of the old Congress to determine on war with the power to declare war. Robert $\mathrm{R}$. Livingston was more direct: "But, say the gentlemen, our present [Confederation] Congress have not the same powers [as the new Congress]. I answer, They have the very same ... [including] the power of making war . . ." 49 During the Pennsylvania convention James Wilson not only implicitly equated declaring war and entering war, but also explicitly foreclosed exercise of the power by the President acting alone:

This [new] system will not hurry us into war; it is calculated to guard against it. It will not be in the power of a single man, or a single body of men, to involve us in such distress; for the important power of declaring war is vested in the legislature at large: this declaration must be made with the concurrence of the House of Representatives: from this circumstance we may draw a certain conclusion that nothing but our national interest can draw us into a war. ${ }^{.0}$

Consistent with these comments indicating a broad view of the power of the new Congress, supporters of the Constitution described the position of the President as Commander in Chief in narrow terms. Most notably, Hamilton contended that the office involved only command in a military sense, with no policy role. The President's authority, he wrote,

would be nominally the same with that of the King of Great Britain, but in substance much inferior to it. It would amount to nothing more than the supreme command and direction of the military and naval forces, as first general and admiral of the confederacy; while that of the British king extends to the declaring of war, and to the raising and regulating of fleets and armies; all which by the constitution under consideration would appertain to the Legislature. ${ }^{.1}$

48. The FeDeralist No. 41, at 270. Madison reiterated this view in the Virginia convention. See 3 Elliot, Debates, supra note 41 , at 259.

49. 2 id. at $278,284$.

50. Id. at 528 .

51. The FeDeralist No. 69, at 465 . 
James Iredell, who contended that "[o]ne of the great advantages attending a single Executive power is the degree of secrecy and dispatch with which on critical occasions such a power can act," ${ }^{2}$ nevertheless described the office of Commander in Chief in a constrained fashion strikingly similar to Hamilton's portrayal. ${ }^{53}$

In accordance with this view, the federalists ignored a clear opportunity to describe the office of Commander in Chief in broad terms. At issue was the fear harbored by contemporaries that joining the purse with the sword would promote tyranny. There was a check in this regard even in England, where, as Patrick Henry observed, "The King declares war; the House of Commons gives the means of carrying it on." 54 The Constitution, though, would join the two powers in the new central government or, according to a noteworthy variation of the argument, in Congress. ${ }^{55}$ The antifederalists, of course, preferred to remedy the situation by giving the states greater control over taxition and the raising of armies-a solution obviously unacceptable to the Constitution's supporters, who, however, were not themselves united on the issue. Hamilton and Madison defended the proposed arrangements in part by claiming that the Constitution did separate the purse and the sword, with Congress holding the one and the President the other; but on balance they tended not to emphasize this division. Instead, to meet the antifederalist argument, Hamilton and Madison drew attention to the need for federal control of the purse and thereby avoided stressing a broad role for the President as Com. mander in Chief. ${ }^{50}$ Other federalists, showing even more reluctnnce to take an expansive view of the executive's power in this area, produced a different and revealing defense. "Are the people of England more secure," asked John Marshall, "if the Commons have no voice in declaring war? or are we less secure by having the Senate [sic] joined with the President?" ${ }^{27}$ Oliver Ellsworth posed a similar question:

[D]oes it follow, because it is dangerous to give the power of the sword and purse to an hereditary prince, who is independent of the people, that therefore it is dangerous to give it to the Parlin-

52. Ford, Pamphlets, supra note 43, at 352.

53. See 4 El.lot, DeBates, supra note 41 , at 107-08. Iredell was not inconsistent in these two positions, for his quotation in this paragraph comes from a discussion of presidential conduct during war.

54. 3 id. at 172 .

55. See 2 id. at $376-77 ; 3$ id. at $172,378-79$. For the sources of the concern over the joining of purse and sword, see May, supra note 27; EkIRCH, supra note 47, at 3.24; $L$. Smith, American Democracy and Military Power 20.24 (1951).

56. See 2 Elliot, Debates, supra note 41 , at $348-51$; 3 id. at 393-94.

57. Id. at 233. 
ment-to Congress, which is your Parliament-to men appointed by yourselves, and dependent upon yourselves? This argument amounts to this: you must cut a man in two in the middle, to prevent his hurting himself. ${ }^{58}$

When judged against future developments, "Publius" may have been "understandably wrong ... in giving a purely military cast to the President's authority as commander-in-chief," cates that his view in this respect accorded well with that of his contemporaries in the state debates.

Even so, federalist comments about the desirability of governmental energy, efficiency, and dispatch are sometimes taken to indicate a latitudinarian view of the executive rvar-making power. ${ }^{60}$ Indeed, during the ratification controversy, the federalists contended that the proposed national government's enhanced ability to raise armies and build fleets would promote national security, in part by deterring

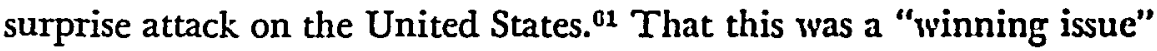
suggests contemporaries were probably not convinced that the constitutional provision allowing state response to surprise attack ${ }^{02}$ was an adequate safeguard by itself, which in turn gives color to the conclusion that they looked to the President to act in cases of sudden attack. But during the ratification debates, the federalists never in fact defended the presidential office on grounds that its energy and dispatch were required in the commencement of war against a foreign enemy in emergency situations. What emerges instead is the conclusion that they were intent on defending the national government without regard to a particular branch. ${ }^{03}$

58. 2 id. at 195. Cf. comments of Edmund Randolph, who had refused to sign the Constitution in Philadelphia and eventually voted for ratification in Virginia only after considerable wavering. 3 id. at 201.

59. Rossiter, Introduction to The Federalst Papers xiii (C. Rossiter ed. 1961). But cf. C. Rossiter, The Supreme Court and the Commander in Cinef 67 (19Ji).

60. See, e.g., Rogers, supra note 28 , at 1196 \& n.10, in which, hovever, the key statement of the argument (the text associated with footnote 10) is simply not supported by a reading of the authorities cited in that footnote. On the discrepancy, compare id., with The Federalist Nos. 49 \& 63 (both Madison, but misassigned by Rogers to Hamilton through use of a nineteenth century edition of The Federalist), Nos. 70.75 (Hamilton). Although certain of these numbers of The Federalist discuss the conduct and dircetion of war (Nos. 70, 72, 74) and the presence of secrecy and dispatch in the Constitution's treaty-making process (i.e., including the Senate) (No. 75), none discusses the topics of the commencement of war or other hostilities against another nation, or the locus-ofpower problem with respect to such commencement.

61. See Marks, Foreign Affairs: A Winning Issue in the Campaign for Ratification of the United States Constitution, 86 PoL. Sa. Q. 444 (1971).

62. See pp. 682-83 supra.

63. See Marks, supra note 61 , at 456.57 , and the citations therein. 
In a similar vein, although the federalists undoubtedly envisioned the Constitution as designed both to meet immediate problems and to comprehend future demands, they seem not to have discussed the allocation of power to commence war in the context of such a theory. Writing in The Federalist Papers, for example, Hamilton boldly noted, "The authorities essential to the care of the common defence ... ought to exist without limitation: Because it is impossible to foresee or define the extent and variety of national exigencies, or the correspondent extent id variety of the means which may be necessary to satisfy them."04 He subsequently reiterated the point: "There ought to be a capacity to provide for future contingencies, as they may happen; and as these are illimitable in their nature, so it is impossible safely :to limit that capacity." ${ }^{65}$ In the first instance, however, he was specifically concerned with the powers "to raise armies-to build and equip fleetsto prescribe rules for the government of both-to direct their operations-to provide for their support." In the second, he was considering the problem of providing an adequate revenue for the proposed government. In sum, although defending the notion of a flexible, expandable Constitution, these statements plainly refer to immediate problems other than that of commencing war. Moreover, Hamilton's broad purpose in both instances was to defend federal power, once more without specification of branch, against exceptions and reservations in favor of the states. ${ }^{60}$

Of course, their silence does not necessarily mean Americans in the late 1780 's rejected the idea that the President had responsibility to respond to sudden attack. Particularly in view of the common expectation that George Washington would be the first President, ${ }^{07}$ it is conceivable that they simply and tacitly assumed that there would be a presidential role in this regard. There was certainly sentiment present in the Federal Convention that " $[t]$ he Executive shd. be able to repel ... war" as Roger Sherman had explained. ${ }^{68}$ What the preponderance of evidence suggests, however, is that if men of the day generally shared such an assumption, they still conceived of the President's war-making role in exceptionally narrow terms.

64. The Federalist No. 23 , at 147.

65. Id. No. 34 , at 211.

66. See id. Nos. 23, 34. See generally id., Nos. 23-36 (A. Hamilton).

67. See, e.g., 6 D. Freeman, George Washington: A Blockaphy 117 \& n.l (1954).

68. See pp. 675-77 supra. 


\section{The Theory and Practice of War and Reprisal}

Americans of the revolutionary generation paid considerable attention to a broad range of European and especially English ideas and controversies involving law, government, and international affairs. ${ }^{\circ 0}$ The works of Hugo Grotius, ${ }^{70}$ Samuel Pufendorf, ${ }^{71}$ Emmerich de Vattel, ${ }^{72}$ and particularly Jean Jacques Burlamaqui ${ }^{73}$ were widely read and quoted.it Books by Thomas Rutherforth ${ }^{75}$ and Richard $\mathrm{Lee}^{\mathrm{i} 6}$ (whose work was largely a popularization of the view's of Cornelius van Bynkershoek) ${ }^{i 7}$ appear to have been less widely read but still received attention. ${ }^{78}$ Many of the fairly well educated and cosmo-

69. See, e.g., B. BAILYN, ThE IDEOLOGICAL ORIGINS OF THE AMERICAN REYolution 22-בH (1967); 1 A. Chroust, The Rise of the Legal Profession in .dMerica: Tile Colosill.

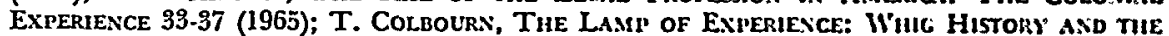
INTEllectual Origins of the AMERican Revolution (1965); Gildest, supra note 3j; MI. Kraus, The Atlantic Civilization: Eightentri Century Origins (1949); Bailjn, Political Experience and Enlightenment Ideas in Eighteenth-Century America, 67 Ass. Hist. REv. 339 (1962).

70. H. Grotius, The Rights of W'ar and PeAce (1625; J. Barbejrac trans. 1738) (to facilitate reference, here and in the following notes $I$ have indicated both an carly cdition and the edition I used) [hereinafter cited as Grorius].

71. S. Pufendorf, ON the Law of Nature and Nations (1688; C. \& W. Oldfather transl. 1994) [hereinafter cited as PUFENDORf].

- 72. E. De VatTel, The Law of Nations (1758; 2 vols. in 1, trans. from French 1759.60) [hereinafter cited as VATTEL].

73. J. Burlamaqui, The Principles of Natural and Polttic Law (2 vols., T. Nugent trans. 1752; 3rd ed. 1784) [hereinafter cited as BuRLAMAQUI].

74. See BaILYN, supre note 69, at 27-29; P. Hasilis, Legal Edtcition in Colonial. NEw York 197-99 (1939); R. Harvey, JeAN Jacques Burlamaqui: A Liberal Trabmox in AMerican Constitutionalisar 79-105 (1937); C. Warken, A History of TuE AMerdCax Bar 163, 181-82 (1911); B. WRIGH, AMERICAN INterpretations of NAturat. LAW 7.8, 44, $50-51,58,60,67,79,89-90$ (1931); Weinfeld, What Did the Framers of the Federal Constitution Mean by "Agreements and Compacts"?, 3 U. CIIt. L. REv. 453, 458.59 (1930); cases cited in note 76 infra. BAILyN, supra, at 28 , cautions, however, that the Americans: knowledge of these works was sometimes superficial; but this was probably less true of the lawyers who used them.

75. T. RUTHERForth, INSTITUTES OF NATURAL LAW (2 vols. 1754-56; Am. Ed. 1799) (also spelled Rutherford) [hereinafter cited as RUTHERFORTH].

76. R. LeE, A Treatise of Gaptures in W'AR (1759) [hereinafter cited as LeE].

77. C. VAN BYNkershoek, A Treatise on the LAW of WAR: Beinc TuE Finst Book of his Quaestionum Juris Publici (1737; P. DuPonceau trans. 1810) [hereinafter citcd as BYNKERSHOEK].

78. In November 1782 the Confederation Congress appointed a committec to compile a list of books to be purchased for its use. In January 1783 the committe reported a list of 309 books, only to have the budget-minded Congress decline to buy urem. The list. which is indicative of recommended reading for the statesman of the 1780 s and of which James Madison was probably the principal author, included not only Lee and Rutherforth but also Grotius, Pufendorf, Vattel, and Burlamaqui. Lee was in Thomas Jefferson's library for the period. Luther Martin read portions of Rutherforth to the Constitutional Convention (Farrand in the index to his Recorps lists this as Samuel Rutherford, but Madison's and Yates' notes contain no indication of a first name, Thomas Rutherforth's name was spelled both Rutherford and Rutherforth, and the context would suggest it was Thomas Rutherforth's work which was being read); Hamilton quoted Rutherforth in Federalist 84; and James Wilson cited Rutherforth in his 1790.91 law lectures. Bynkershoek's Quaestionum appears to have been much less well-known, with the 1783 "states. man's" list merely giving the title of another book of his, followed by "with all his other 
politan men to whom the deferential American society of that day looked for leadership ${ }^{70}$ thus must have been familiar with these treatises. Among the topics the treatises considered were several which helped illuminate the war-making power of the new government being considered in 1787-88. Consequently, these works, in conjunction with historical trends visible in the late eighteenth century, offer further insight into the original understanding of war-making under the Constitution, and particularly the problem of undeclared war.

The writers in question discussed the necessity of declarations of war, but reached no consensus. Although none of them held a declaration necessary in a defensive war, Grotius, Pufendorf, and Vattel thought one required in a non-defensive war, if that war was to be legal with respect to the consequences attaching to it (for example, immunity from criminal prosecution for those waging it). Burlamaqui, however, was not entirely clear on the point. He stated that in a non. defensive war a declaration "ought" to be issued as a token of the respect which sovereigns should show each other, and so left unclear whether there was here a legal obligation or only some principle of comity. The remaining authors contended that a declaration was never legally necessary, but they agreed with Burlamaqui that it was desirable in that it put neutrals on notice to observe their obligations toward the belligerents and allowed the enemy one last chance to give satisfaction. Several of the writers stated that a declaration might be either absolute or conditional. The absolute declaration was a simple and unconditional announcement of war. The conditional declaration was essentially an ultimatum, that is, a demand that the enemy perform some act, coupled with a warning that otherwise war would fol. low as a matter of course with no further notice. ${ }^{80}$

works." Within several years of the Constitution's framing and ratification, Lec, Ruther. forth, and Bynkershoek were all extensively cited by counsel in a number of prize cases heard by the U.S. Supreme Court. See L. Smith, The Library List of 1783, 1969, at 2.8 , 123-25, 127, 129-30 (unpublished Ph.D. dissertation in the Honnold Library of the Claremont Colleges); 2 Catalogue of the Library of Thomas JefFerson 74 (E. Sowcrby comp. 1953); I FARRAND, ReCoRDS, supra note 6, at 438, 440; 4 id. at 209; 1 THE Works of JAMkS WiLSON 163, 192 (R. McCloskey ed. 1967); THE FEDERALIST No. 84; Glass v. The Sloop Betsey, 3 U.S. (3 Dall.) 6 (1794); Talbot v. Jansen, 3 U.S. (3 Dall.) 133 (1795); M'Donough v. Dannery and the Ship Mary Ford, 3 U.S. (3 Dall.) 188 (1796); Bas v. Tingy, 4 U.S. (4 Dall.) 37 (1800).

79. See 1'ole, Historians and the Problem of Early American Democracy, 67 AM. Hist: REv. 626 (1962). In saying that American society of the 1780's was deferential, I do not intend to become involved in the much-debated question of whether it was "democratic," politically or otherwisc. Deference and democracy are not necessarily mutually exclusive.

80. See Grotius 57-58, 552-55; Pufendorf 1294.95, 1307 (Pufendorf mainly refers his readers to Grotius on the subjects of declarations of war and reprisals); 2 VATTEL 3, 21.26; 2 BURLAMAQUi 269-72; BXNKERSHOEK 6-27; LEE 13-39; 1 RUTHERFORTI 451; 2 id. at 522.29, 549.53. 
It must initially be recognized that when these authors spoke of declarations of war, they generally meant formal announcements to the enemy with proper ceremony, usually in his capital. ${ }^{81}$ In point of fact, however, European states had not made such declarations for well over a century. ${ }^{82}$ The common practice was to publish an announcement domestically and to inform the enemy, if at all, by means of a written communication such as a diplomatic note. ${ }^{83}$ To cope with the disparity between theory and practice, Burlamaqui had sought to distinguish between a "declaration" and a "publication" of war. ${ }^{84}$ But, with the possible exception of two American treaties concluded during the revolutionary and Confederation periods, ${ }^{85}$ there appears to have been no acceptance of this distinction in the United States. ${ }^{80}$ In view of these facts, it seems probable that a contemporary would have taken "declaration of war," as used in the treatises, to mean what nations had customarily done in "declaring" war during the preceding century or so. ${ }^{87}$

Once that equation was made, the treatises may well have affected the way those who debated the Constitution in 1787-88 understood the document. One intriguing possibility is that a person familiar with the literature on conditional declarations of war could easily have concluded that Congress might conditionally authorize the President

81. See citations in note 80 supra.

82. This may have been what Hamilton had in mind when he wrote that "the ceremony of a formal denunciation of war has of late fallen into disuse . . . " Tue Feberalist No. 25, at 161 .

83. See G. Martens, Sumarary of the Law of Nations Founded in the Treaties and Customs of THE MODERN NATIONS OF Europe 274-75 (1788; W. Cobbell trans. 179j); $2 \mathrm{~J}$. WeSTLAKE, INTERNATIONAL LAW 20-21 (2d cd. 1913).

84. 2 Burlamaqui 272-73. Vattel hinted at the same distinction (see 2 Vattel 25), but generally used "declaration" to include both formal denunciation to the enemy and publication.

85. In their English (i.e., American) texts, the Treaties of Amity and Commerce with France, Feb. 6, 1778, 8 Stat. 12 (1778), T.S. No. 83, and the Netherlands, Oct. 8, 1782, 8 Stat. 32 (1782), T.S. No. 249, used the phrase "proclamation of war" in articles (22 and 18, respectively) relating to the effects of an announcement of war within the announcing nation and used "declaration of war" elsewhere. The French and Dutch texts did not observe the distinction. See 8 Stat. 12, 32 (1778, 1782), 2 T.I.A.S., 2 Treaties ANo Otuen INTERnational ACTS OF THE UNITED States of AMerica 3, 59 (H. Ailler ed. 1931). The original instructions of the Continental Congress regarding the French treaty (the so-called Treaty Plan of 1776) also included the distinction. See 5 Journals of TIIE CONTINENTAL Congress 1774-1789, at 774 (1906). Other contemporary American treaties ignored it.

86. See, e.g., Treaty of Amity and Commerce with Sweden, April 3, 1783, 8 Stat. 60 (1783), T.S. No. 346, 2 Treaties aNd OTHER INTERnational ACTs, supra note 8j, at 123; Convention of Peace, Commerce, and Navigation with France, Sept. 30, 1800, 8 Stat. 178 T.S. No. 85, 2 Treaties AND Other INTERNATIONAL ACTs, supra, at 457. These used "declaration of war" in contexts similar to those in which the treaties cited in note 85 supra used "proclamation of war."

87. That at least some writers in the general period did so is seen in J. Kest, Dissertations, Being the Preliminary Part of a Course of Laiw Lectures 60 (1795); Matsteis, supra note 83 , at 274-75. 
to conduct a war if another nation refused to meet American demands. ${ }^{88}$ More importantly, though, the treatise writers' contention that declarations were not needed in defensive wars raised the question of undeclared war, and this was a matter that the treatises considered at some length.

Grotius had argued that declared war was "perfect" war in the sense of being complete-that is, involving whole nations on each side. Accordingly, undeclared war was "imperfect." The latter occurred "where no perfect War is absolutely denounced; yet where a certain violent protection of our rights is necessary," with the violence consisting of state-authorized private reprisals directed at property held by the subjects of another nation. ${ }^{80}$ The later commentators agreed that imperfect war and reprisals were closely related, if not identical, but they took a broader view of what constituted reprisals, holding that states using public forces might themselves make reprisals. Burlamaqui's view is representative:

A perfect war is that which intirely interrupts the tranquillity of the state, and lays a foundation for all possible acts of hostility. An imperfect war, on the contrary, is that which does not intirely interrupt the peace, but only in certain particulars, the public tranquillity being in other respects undisturbed.

... This last species of war is generally called reprisals, of the nature which we shall here give some account. By reprisals then we mean that imperfect kind of war, or those acts of hostility which sovereigns exercise against each other, or, with their consent, their subjects, by seizing the persons or effects of the subjects of a foreign commonwealth, that refuseth to do us justice .....90

88. It would probably be anachronistic to equate such a view with permissiveness toward delegation of power in the modern sense.

89. See Grotius 538-49 (the quotation is at 540). See also id. at 57-58.

90. 2 BURlamaqu 258. See LEE 20,40-51; 2 Rutherforth 485, 516, 522.23, 537.53; 1 VATTEL 249-51; 2 id. at 25-26 (but Vattel's equation of imperfect war with reprisils is less completely developed than that of the other writers); 1 M. HALE, Historia PLAcitokuM Coronae: The History of the Pleas of the Crown 162 (S. Emlyn ed. 1736). Hale's comments in this regard are particularly significant, because, compared with other English jurists prior to Blackstone, "Hale was a particularly well-known and attractive figure" to Americans. BAILYN, supra note 69 , at $30 \mathrm{n} .11$. It is also noteworthy that language practically identical to that in the first paragraph of the quotation from Burlamaqui was included, but without citation in Miller v. The Ship Resolution, 2 U.S. (2 Dall.) 1, 21 (Ct. App. in Cases of Capture 1781). Suggestive of the broadened concept of reprisals is this comment from an American about twenty years after the framing and ratification of the Constitution:

Reprisals are either general or special.-They are general when a sovereign, who has or thinks that he has received an injury from another prince, issties orders to his military officers, and delivers commissions to his subjects to take the persons and property of the other nation, wherever the same may be found. It is, at present, the 
There was consensus that imperfect war and state reprisals, commonly called general reprisals, could easily lead to perfect war. ${ }^{01}$

These opinions of the eighteenth century authors comported with two features of recent history, as seen in the late $1780^{\circ}$ s. First, hostilities without declarations of war were common during the period. Indeed, the undeclared hostilities in 1754-56 which marked the beginning of the Seven Years War between Britain and France, occurred mainly in America. During the War of the American Revolution, moreover, Britain and France never expressly declared war on each other, unless France's treaty with the United States may be so construed.02 The second feature involved the practice of European states with respect to reprisals. From the twelfth through the seventeenth centuries, these states had regularized and legitimated private reprisals in time of peace by the sovereign's granting of letters of marque and reprisal to individuals who had specific claims against subjects of other states. Such letters authorized seizure of the property and sometimes the persons of the other state's subjects. When issued during war, the letters empowered individuals who were not members of public armed forces to take from the enemy and his subjects. Then, during the first half of the eighteenth century, the practice of granting letters of marque and reprisal for satisfaction of private claims during peace virtually disappeared. States, however, continued to make reprisals to press their own claims, using both public naval forces and private ships sailing under privateer commissions or letters of marque and reprisal. These state or general reprisals not uncommonly resulted in outright war. English history furnished several such examples which were undoubtedly familiar to those who debated the Constitution: the wars with the Netherlands in 1652 and 1664, with Spain in 1739, and with France in 1756 were all preceded by public naval reprisals..$^{.3}$

first step which is generally taken at the commencement of public war, and is considered as equivalent to a declaration of it.

Special reprisals are granted, in time of peace, to individuals who have suffered an injury from the subjects of another nation .....

ByNkerShoek 182 n. * (trans. note). See generally 7 J. Moore, A Dicest of Intensitional. LAW $119-30$ (1906).

91. See 2 Burlamaqui 261; Lee 20, 45; 1 Vattel 250. See also Grotits 57-60. While Rutherforth does not explicitly deal with the point, neither does he contradict the conclusions of the other writers on it.

92. See J. Maurice, Hostilities Wrthout Declaration of War 1700.1870. al 12.26 (1883); 3 R. Phillimore, Commentaries on INTERnational LAW 110-15 (1857); 2 W'estlahe, supra note 83, at 22-23. Phillimore contends (at 115 ) that France's announcement of her American treaties in 1778 had the effect of a declaration.

93. See A. Hindmarsh, Force in Peace: Force SHort of W'ar in Intersational RelaTIONs 43-56 (1933); 3 Phillmore, supra note 92, at 103-09, 118; Maccoby, Reprisals as a 
In sum, familiarity with Grotius and his successors and with thenrecent history would have suggested to one in the late 1780's that undeclared war was no oddity and that the issuance of letters of marque and reprisal for satisfaction of private claims was outmoded. An American who was knowledgeable about these topics therefore faced the problem of explaining the Constitution's use of the wording "declare" and "letters of marque and reprisal." He might have done this in several ways, but certain interpretations would have made more sense to him than others.

In regard to the word "declare," he might have settled on any of a variety of possibilities:

(1) America would restrict herself to fully declared wars. However, this interpretation would have run counter to the prevalence of undeclared war in the eighteenth century, which would have been a matter of some importance to a generation that made a practice of deriving lessons from history. ${ }^{94}$ In addition, it would have contradicted a goal of the new diplomacy with which Americans were so enamored, namely, that force should be restricted and the effects of war controlled. ${ }^{55}$ Indeed, in 1785 provisions reflecting this goal had been in. cluded in the Treaty of Amity and Commerce between the United States and Prussia. ${ }^{96}$ But fully declared wars were less likely to be lim. ited in their material dimensions.

(2) The provision giving Congress the power to declare war was merely a formality. In practice, America would avoid war by limiting her relations with the world to trade and commerce. ${ }^{97}$ Many Americans undoubtedly hoped the United States could remain aloof from war, but a generation which avidly followed European affairs, which had confronted European activities in America and Barbary depredations in the Mediterranean during the $1780^{\prime} \mathrm{s}^{98}$ and which contained some

Measure of Redress Short of War, 2 CAMb. L.J. 60, 60-67 (1924); 1 LETTERS AND PAiERS ReLATING to THE FIRST Dutch WAR 1651-54, at $301-02$ (S. Gardiner ed. 1899); 2 TiE RoYAL Navy: A History $422-25$ (W. Clowes ed. 1898); 3 id. at 51-52, 266-67; 1 J. Conuetr, EnG. LANd in the Seven Years War 83 (2d ed. 1918).

94. See Adair, "Experience Must Be Our Only Guide": History, Democralic Theory, and the United States Constitution in The ReINTERPRETATION OF EARLY AMERICAN His. TORY 129 (R. Billington ed. 1966); ColboURN, supra note 69 passim and especially $4.6,185$. 95. See generally works cited in note 36 supra.

96. Treaty of Amity and Commerce with Prussia, Sept. 10, 1785. 8 Stat. 84, 94.96, T.S. No. 292, 2 Treaties and Other INTERnational Acts, supra note 85, at 162, 178.79. This provision followed the instructions of Congress. See 26 Journals of THE CoNTINENTAL CONGRESS 1774-1789, at 358-59 (1928).

97. See T. Paine, Common Sense and Other Political Writincs 22-23 (Libcral Arts Press ed. 1953). See generally the works cited in note 36 supra.

98. See, e.g., T. Bailey, A Diplomatic History of the AmERican Peorle 52.65 (8th cd. 1969). 
eminent realists ${ }^{99}$ would hardly have counted on the complete disappearance of war.

(3) Congress' power to declare war was to be interpreted strictly; as a result the Constitution left the waging of undeclared war unaccounted for. Authority over it must have been either unvested or perhaps somewhat deviously vested in the executive branch. It seems unlikely, however, that an observer in 1787-88 would have concluded that the Constitution would leave such an important power unvested. Certainly no one commented on the omission. It also seems improbable that a contemporary would have accepted the alternative that the powver was lodged with the executive. Contemporaries spoke and wrote in narrow terms of the President's sole martial role as Commander in Chief. ${ }^{100}$

(4) As used in the Constitution, "declare" had a broader meaning than it did in the treatises and international practice. It meanl "commence." This interpretation, unlike the first three possibilities I have discussed, would probably have seemed plausible to someone in 178788, because contemporary statements suggested that the power of the new Congress to commence war would be at least as broad as that of the Confederation Congress. ${ }^{101}$ This deviation from international usage would have seemed proper, as well, since the Constitution involved domestic arrangements.

(5) Whatever the scope of the term "declare" as used in the Constitution, any war-commencing power not covered by it was vested in Congress by virtue of that body's control of reprisals. This possibility, which is at once distinguishable from, yet compatible with interpretation (4), would also have seemed plausible because the treatises closely assimilated imperfect war and reprisals.

The last interpretation suggests the need for more detailed consideration of how an observer, acquainted with the treatises and the relevant history, would have interpreted the Constitution's grant to Congress of power to issue letters of marque and reprisal. Here, too, there are several possibilities:

(1) The phrase "letters of marque and reprisal" was used in the Constitution in a technical sense and was intended to give Congress authority to grant such letters to private individuals in both peace and

99. See, e.g., R. Hofstadter, The American Polmical Tradition and tue Mev Who MAde It 3-17 (1954).

100. See pp. 679-80, 685-87 supra.

101. See p. 685 supra. 
war. This interpretation, however, ignores the fact that special letters of marque and reprisal, for the peacetime satisfaction of private claims, had fallen into disuse and general reprisals had become the rule. As a necessary and proper concomitant of the powers to commence and conduct war, letters could be issued in war whether or not the Con* stitution mentioned them. In fact, if granted during a declared war as a military measure, there could be little objection to their being granted by the President, who, as Commander in Chief, was charged with the conduct of war. Under this interpretation, then, the phrase would have been archaic and redundant in intent.

(2) The power was merely a careless and meaningless carry-over from the Articles of Confederation. ${ }^{102}$ A contemporary would have noted, though, that the Convention had given new attention to the problem of letters of marque and reprisal. The states, which could issue such letters in time of war under the Articles, were altogether prohibited from issuing them under the Constitution. ${ }^{103}$ Thus it would have seemed unlikely that the retention of the power was meaningless.

(3) The phrase most importantly conferred on Congress power over general reprisals outside the context of declared war. While the worcling in question admittedly spoke broadly of granting "letters of marque and reprisal," issuance of the special variety had passed out of fashion in peace time. The clause thus could easily have been interpreted as serving as a kind of shorthand for vesting in Congress the power of general reprisal outside the context of declared war. ${ }^{104}$ For someone in the late 1780 's, this interpretation, far more than the first two, would have given the phrase meaning and would have been consistent with history and the treatises. Once accepted, this

102. Of course, what we know about the history of the clause in the Philadelphin Convention (see p. 679 supra) was generally unknown in 1787.88 .

103. ARTs. OF Confed. art. VI; U.S. CONST. art. I, $\$ 10$.

104. The making [of] a reprisal on a nation is a very serious thing. Remonstrance and refusal of satisfaction ought to precede; and when reprisal follows, it is consid. ered an act of war, and never failed to produce it in the case of a nation able to make war; besides, if the case were important and ripe for that step, Congress must be called upon to make it; the right of reprisal being expressly lodged with them by the Constitution, and not with the Executive.

Opinion of Thomas Jefferson, Sec'y of State, May 16, 1793, quoted in $7 \mathrm{~J}$. Moone, INT'L. LAw Digesr 123 (1906) (emphasis added). On the matter of the wording regarding reprisals serving as shorthand, cf. L. Levy, Origins of THE FIFTi AMENDMENT 430 (1968): "[C]on. stitution-makers, in that day at least, did not regard themselves as framers of detailed codes. To them the statement of a bare principle was sufficient . . . " The same point might also be made in connection with the equation of "to declare war" and "to com. mence war." 
interpretation in turn would have given increased plausibility to the view that Congress possessed whatever war-commencing power was not covered by the phrase "to declare war."

In short, while one cannot pretend that the matter is beyond all doubt, it seems plain that knowledge of the theory and practice of war and reprisal would have helped convince a late-eighteenth century American that the Constitution vested Congress with control over the commencement of war, whether declared or undeclared.

\section{English Influences}

If, as the preceding discussion indicates, Americans in 1787-88 saw Congress as having the dominant voice in the commencement of war, they were breaking with English constitutional theory under which war-making was a Crown prerogative. ${ }^{105}$ This is not surprising, for the scope of executive power in America narrowed considerably after independence. In the late 1780 's, of course, the trend toward weaker executives was reversed. The reversal, however, resulted from domestic considerations-stronger and more independent leadership seemed necessary to insure liberty and stability within the countryand it had little or no connection with external problems of warmaking. ${ }^{106}$ Departure from English theory concerning the initiation of war was therefore consistent with broader developments in postindependence America.

Although the English theoretical model lost favor in America, prior English experience and thought were still quite relevant to the evolving American view of war-making. Even in England itself, practice did not coincide with theory. In the seventeenth century, Sir Matthew Hale had written: "The power of making war or peace ... in England is lodged singly in the King, tho it ever succeeds best when done by parliamentary advice."107 In 1775 another student of the English constitution, Jean de Lolme, commented that the King

has the prerogative of commanding armies, and equipping fleets -but without the concurrence of his Parliament he cannot maintain them .... He can declare war-but without his Parliament

105. 1 W. BLACKstone, CoMmentaries '249-50.

106. See G. WoOd, The CReation of the AMericas Repubuc 1776-1787 passim and especially at 393-564 (1969).

107. 1 HaLE, supra note 90 , at 159 (emphasis added). 
it is impossible for him to carry it on. In a word, the Royal prerogative, destitute as it is of the power of imposing taxes, is like a vast body, which cannot of itself accomplish its motions . . . 108

Hale and de Lolme, of course, were not directly considering the theoretical locus of the war-making power in England. They asserted only that parliamentary control over the war-supporting function provided practical checks on the King's prerogative. On the basis of such analy. ses, however, the English system did not present a polar contrast to the evolving American notions of congressional control over warmaking. Rather, it contained elements which, on the one hand, were imitated in the American Constitution with its provisions for a clear legislative monopoly of the war-supporting function, and, on the other, suggested tendencies toward legislative control of the war-making function itself. 109

Other English sources which Americans probably noted would have led them to similar conclusions about the desirability of a diminished executive role in war-making. The English commonwealthmen of the seventeenth and eighteenth centuries, whose views were especially ap. pealing in America, admittedly did not emphasize the problem of warmaking as such. Their major concern regarding military matters was that standing armies posed a domestic threat. Their outlook nonetheless generally favored a diminished executive role. ${ }^{110}$ The same was true of the broader group of Whig writers who proved so popular in revolutionary America. ${ }^{111}$ In 1774, James Burgh went so far as to imply that Parliament should have a substantial and independent voice not only in the supporting of war, but also in its commencement, conduct,

108. J. De Lolme, The Constitution of England 48 (1775). See generally id. at 47.62.

109. Of course, the development of cabinet government in England blocked the growth of an independent parliamentary check on the executive. The cabinet, with or without the Crown's connivance, came both to exercise executive functions and to manage par. liament. But to the extent that they were aware of these tendencies toward cabinct gove ernment, eighteenth century Americans deprecated them as manifestations of the corrup. tion-that is, the improper use of influence-which they thought was so generally menacing to a proper balance in government and hence to liberty. See B. BAILYN, TuE Origins of American Politics 14.58 (1968); M. Thomson, A Constitutional Histoky of ENGLand $1642-1801$, at 353.84 (1938).

110. See C. Robins, The Eichteenth Century Commonwealthman (1959), But at least one of the commonwealthmen, Henry Neville $(1620.1694)$, was explicit in his desire to "take from the king the power of making war and peace . . . ." Id. at 39. Far from a coherent group, the English Commonwealthmen or Real Whigs were intellectual descendants of the Puritan revolutionaries of the 1640's and 1650's. They had republican and non-conformist tendencies and were enamored of natural right theories, frecdom of thought, limited government, and parliamentary reform. By the end of the eightecnth century, they had merged into the broader stream of English radicalism. See id. passim.

111. See Colbourn, supra note 69 , passim. 
and conclusion. ${ }^{112}$ John Locke, writing some ninety years earlier, had separated what he called the federative power, which included warmaking, from the ordinary executive power. He saw the same authority as properly exercising both powers, but his separation of them for purposes of analysis may have aided in establishing a basis for their later actual separation. ${ }^{113}$ At any rate, Thomas Rutherforth was explicit in his opinion in the 1750's that war-making was a legislative function because it had to rest on the "common understanding" of the nation. ${ }^{114}$ All considered, it is not surprising to find that at the Philadelphia Convention James Madison and James Wilson characterized war-making as properly legislative.115

\section{Conclusion: The Original Understanding in Theory and Early Practice}

Although the change from "make" to "declare" in the clause empowering Congress "to declare War" was open to several interpretations among the members of the Philadelphia Convention, there is enough evidence to allow some cautious generalization about the original understanding concerning war-making. The Confederation Congress exercised both legislative and executive functions; the new Congress would not. Nevertheless, specific remarks equating the warmaking powers of the two Congresses, together with other comments about war-making being a legislative function, suggest that contemporaries thought the power of the proposed legislature to commence war would be as broad as that of the Confederation Congress. Since the old Congress held blanket power to "determine" on war, and since undeclared war was hardly unknown in fact and theory in the late eighteenth century, it therefore seems a reasonable conclusion that the new Congress' power "to declare War" was not understood in a narrow technical sense but rather as meaning the power to commence war, whether declared or not. To the extent that the power was more narrowly interpreted, however, the new Congress' control over letters

112. See $1 \mathrm{~J}$. Burgh, Polttical Disquistrions: Or AN Engutry Into Public Ersors, DefEGTS, ANd ABuses . . . 371 (1774). See also id. at 193.95, 414-45.

113. See J. Locke, The Second Treatise of Governatent 83.84 (Liberal Arts Press cd. 1952).

114. 2 RUTHERFORTH 64-67.

115. See p. 679 supra. See also 1 The Works of JAMEs Wilson, supra note 78, at 433-34 (Wilson's 1790-91 law lectures). 
of marque and reprisal must have suggested to contemporaries that it would still control "imperfect"-that is, undeclared-war. Otherwise, the provision involving such letters would have seemed practically meaningless in view of the status of reprisals by the late 1780's. Taken together, then, the grants to Congress of power over the declaration of war and issuance of letters of marque and reprisal likely convinced contemporaries even further that the new Congress would have nearly complete authority over the commencement of war. Reinforcing the same conclusion is the fact that English experience, and particularly the English Whigs to whom Americans paid considerable attention, offered hints about the desirability of legislative supremacy in this area. It remains possible that the President as Commander in Chief was tacitly accorded the initiative to meet sudden attacks on the United States. In their public statements, however, contemporaries assigned him the restricted military role of conducting war once it had begun. In any event, the Constitution explicitly authorized the states to act in the face of surprise attack.

The consensus which existed in 1787-88 on the war-making issue did not last, and Hamilton as "Pacificus" began lodging reservations as early as 1793. It is significant, though, that his position appears not to have been an especially persuasive one even to his fellow Federalists, ${ }^{116}$ let alone to the Republicans. In 1795, James Kent contended that in the United States "war only can be commenced by an act or resolution of Congress," indicating that he equated "declare" with "commence." 117 The undeclared hostilities with France during John Adams' administration were authorized by Congress, ${ }^{118}$ and despite debates over the extent to which specific legislative measures provided a basis in law for action against the French, the notion that authorization must come from Congress was seldom challenged. ${ }^{110}$ At one point, when the Republicans in the House of Representatives proposed to modify and weaken legislation authorizing American naval reprisals against the French, an exasperated Federalist protested that preservation of American rights required the legislation to be passed unamended, because "the President has not the power to act in the

116. That is, members of the Federalist Party, not to be confused with the lower casc " $f$ " federalists of the ratification controversy in 1787-1788.

117. KENT, supra note 87 , at 83 .

118. See A. DeConde, The Quasi War: The Politics and Diplomacy of the Unde. CLARED WAR WITH FRANCE $1797-1801$ passim and especially at 89.98 (1966).

119. See, e.g., The Debates and Proceedings in the Congress of the Unired States, 5th Cong., 2d Sess. cols. 1440-1522, 1783, 1798-1812, 1815-35 (1798). 
[present] case. Congress only [can] authorize reprisals."120 Retreating from the position he had earlier taken as "Pacificus," Alexander Hamilton held that the Constitution narrowly constrained the President's actions. Adams might authorize the repelling of actual attacks, but he could not make reprisals without congressional approval. ${ }^{121}$

In two maritime prize cases arising out of the Quasi-War, the Supreme Court of the United States evinced similar views. The seriatim opinions in Bas $v$. Tingy (1800) ${ }^{122}$ stressed that whether hostilities were declared or undeclared, they still constituted war-being perfect and general war in the one case, and imperfect and limited war in the other. None of the Justices explicitly stated that only Congress might wage imperfect war, but that conclusion was clearly implicit in their remarks. ${ }^{123}$ In Talbot $v$. Seeman (1801), a case involving the salvage rights of Silas Talbot and his officers and crew, John Marshall, the newly appointed Chief Justice, forthrightly stated: "The whole powers of war being, by the Constitution of the United States, vested in congress, the acts of that body alone be resorted to as our guides in the enquiry." He further argued that such powers included the authorization of limited hostilities, which he, too, obviously regarded as war, for he explicitly referred to the recent conflict with France as "war." I24

Evidence from the years immediately following ratification of the Constitution thus corroborates the conclusion that Americans originally understood Congress to have at least a coordinate, and probably the dominant, role in initiating all but the most obviously defensive wars, whether declared or not. Since that time, and especially during the twentieth century, the presidential role in war-making has nevertheless become dominant. Somerwhat in the manner of Teddy Roosevelt and the Panama Canal, while Congress and others have debated, Presi-

120. Id., col. 1828 (Representative James A. Bayard).

121. I Naval Docusents Related to the Quasi-War Between the UNited States ANd France 75-76 (1935) (letter from Hamilton to Sec'y of War J. MeHenry, May 17. 1798). See also id. at 78 (letter from Sec'y of War J. MeHenry to Captain R. Dale. US.:. May 22, 1798). On the general conclusions contained in this paragraph, sec Russell, supra note 6, at 65-100 (for the Federalist period 1789-1801) and 102-46 (for the Republican period, 1801-1815)

122. 4 U.S. (4 Dall.) 37 (1800).

123. See, e.g.:

Congress is empowered to declare a general war, or congress may wage a limited war; limited in place, in objects, and in time. If a gencral war is declared, its extent and operations are only restricted and regulated by the jus belli, forming a branch of the law of nations; but if a partial [war] is waged, its cxtent and operation depend on our municipal laws [as passed by Congress].

Id. at 43 (Chase, J.).

124. Talbot v. Seeman, 5 U.S. (1 Cranch) 1, 28, 32 (1801). On the conflict's status as war, see 1 Op. ATI'Y GEN. 84 (1798) (C. Lee to Sec'y of Statc). 
dents have acted. How long this situation will continue is difficult to predict, though the constitutionality of recent practice is an intriguing question which promises to attract further national attention. ${ }^{125}$ Whether the original understanding properly concludes the issue undeniably involves questions quite different from those I have here discussed. Still, paying it some heed is surely consonant with a devotion to constitutionalism.

125. On April 13, 1972, the Senate passed a bill to regulate undeclared war. Sce S. 2956, 92d Cong., lst Sess. (1971) ("A bill to make rules governing the use of the Armcd Forces of the United States in the absence of a declaration of war by the Congress"). N.Y. Times, Apr. 14, 1972, at 1, col. 6 (city ed.). Though the bill passed 68.16 , resistance from both the House and the Executive is likely. See Bickel, The Need for a War.Powers Bill, New Republic, Jan. 22, 1972, at 17. For earlier bills and resolutions of this sort, see, e.g., S. 731, 92d Cong., lst Sess. (1971); S. J. Res. 95, 92d Cong., 1st Sess. (1971); and nineteen House bills and resolutions reprinted in 1970 Hearings on Congress, the Presi. dent, and the War Powers, supra note 4, at 435.76 . 